
$F$
786
.$R 58$

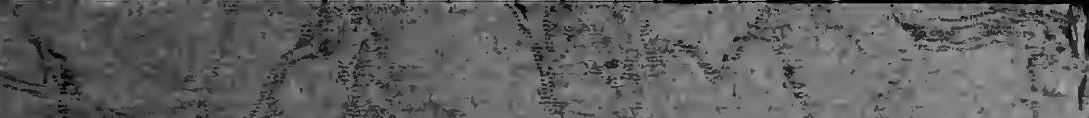

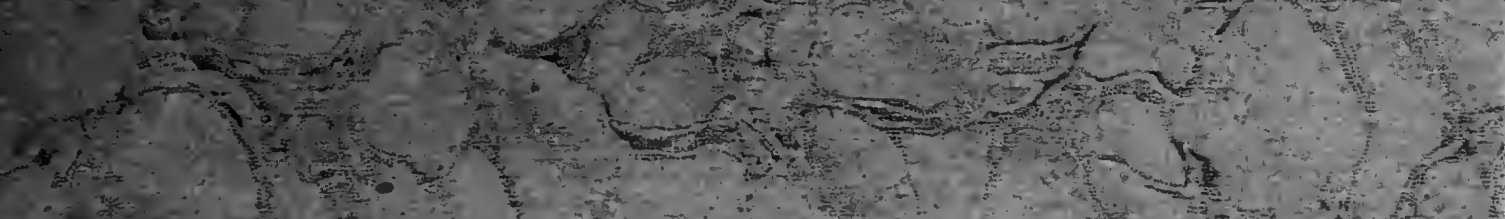

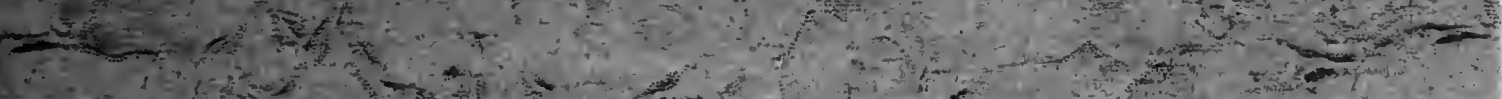
$3 \rightarrow 1$ if $x^{2}-1$

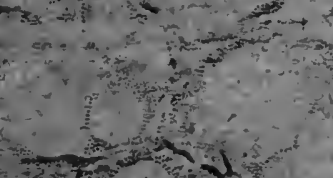
$y+x+4$ Ext

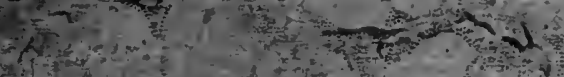

$4 x=4$

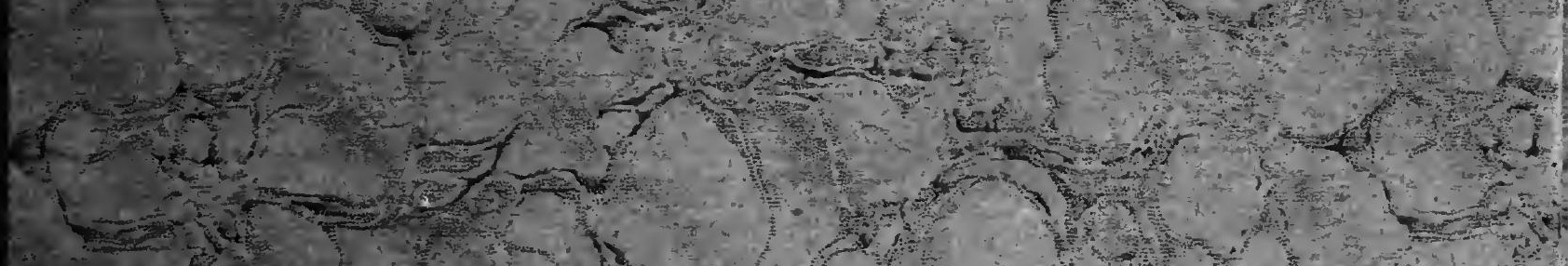

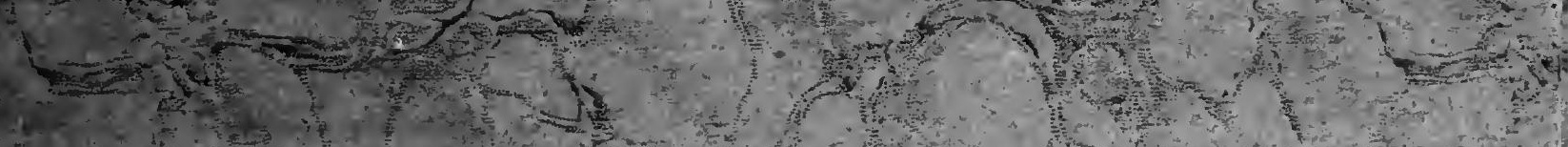

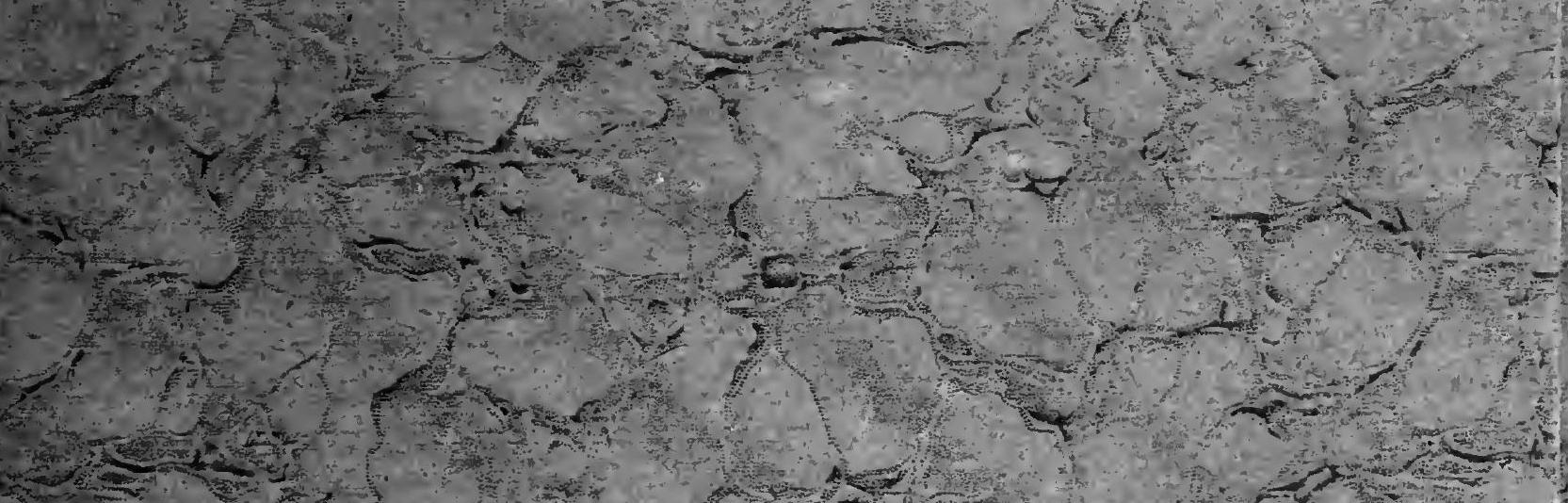

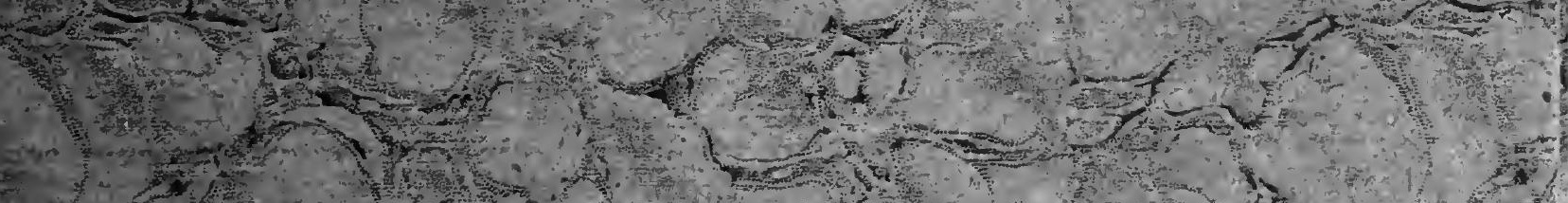

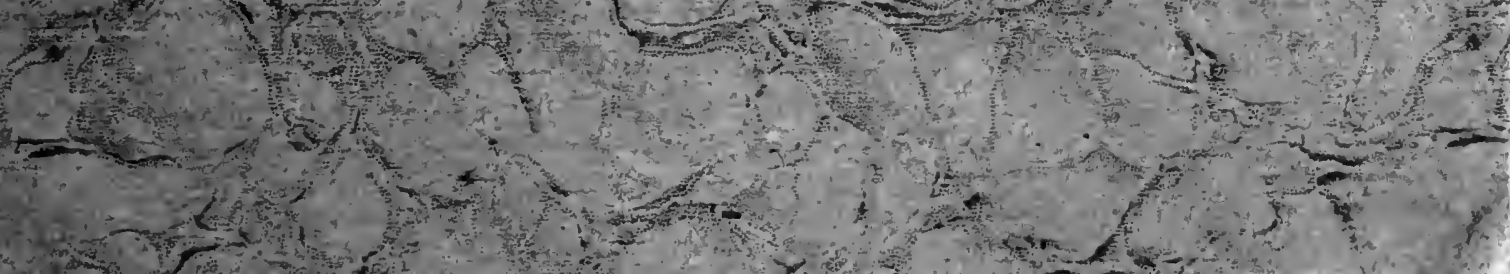




\section{The Indians of the Southwest in the Diplomacy of the United States and Mexico, 1848-1853}

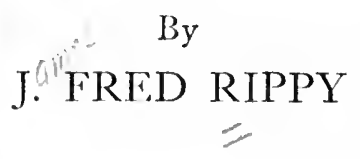

Dr. R.A.dyer

with the complininats of the actior

Reprinted from The Hispanic American Historical Review,

Vol. II, No. 3, August, 1919 
Digitized by the Internet. Archive in 2007 with funding from Microsoft Corporation 


\section{THE INDIANS OF THE SOUTHWEST IN THE DIPLOMACY OF THE UNITED STATES AND MEXICO, 1848-1853 ${ }^{1}$}

Article XI. of the treaty of Guadalupe Hidalgo.-The chief subjects of diplomatic discussion between the United States and Mexico from 1848 to 1853 grew out of three points which the treaty of Guadalupe Hidalgo failed to settle in a satisfactory manner. These were the disposition of the Indians in the territory which changed sovereignty, the marking of the boundary, and the question of interoceanic communication by way of the Isthmus of Tehuantepec. By Article XI. of the treaty, the United States government assumed responsibility for the Indians residing immediately north of the new boundary. It is the purpose of this paper to consider the efforts of that government to meet this obligation, its ultimate failure, and its final release from what was discovered to be a bad bargain.

The main provisions of the rather lengthy article may be summed up as follows:

1. The United States agreed to restrain the Indians ranging along the international border and within its limits from their incursions upon Mexico and to punish and exact satisfaction for such incursions when they could not be prevented.

2. It was to be unlawful for inhabitants of the United States to purchase captives or property taken by Indians from Mexico.

3. In case Mexican captives were brought into its territory, the United States was to rescue them and return them to the proper Mexican authorities.

4. The United States was to pass without delay all laws necessary to the enforcement of these provisions and, in the removal

1 The writer wishes to acknowledge his indebtedness to Dr. Charles E. Chapman, at whose suggestion this monograph was undertaken, and to Dr. Herbert E. Bolton, whose seminar papers he has freely used.

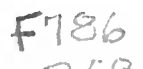


of the Indians, the protection of Mexico was ever to be borne in mind. ${ }^{2}$

Factors Leading to the Acceptance of the Article.-In his message of December 7, 1847, President Polk, seeking to justify the claim of the United States to New Mexico, suggested that Mexico might even desire to place the province under the United States, for she had been, and was at that time, too weak to restrain the wild Indians from their depredations upon it as well as upon other North Mexican States. "If New Mexico were held and governed by the United States", Polk argued, "we could prevent these tribes from committing such outrages and compel them to release the captives and to restore them to their families and friends". ${ }^{3}$ While negotiations were in progress, the delegation of Chihuahua had recommended that "no treaty be concluded which shall [should] not establish sufficient security that neither the government of the United States, nor the citizens thereof, shall [should] buy from the savages the plunder obtained from robberies committed within Mexican territory, nor furnish them . . . with means for making war, nor drive them upon our territory by purchasing from them their lands, nor favor their incursions directly or indirectly".4

In commenting upon the article, Trist, the American negotiator, declared that the assumption of responsibility for the Indians was "indispensable to make the treaty acceptable to the northern States [of Mexico], or to any who take the proper interest in their security; in a word, to anyone who has the feelings of a Mexican citizen, or at least respect for the obligation which a federal union imposes". ${ }^{5}$ At the same time he sought to lighten anticipated opposition on the part of his home government by suggesting that the obligation did not differ essentially from that assumed by the $33 \mathrm{~d}$ article of the treaty of amity, commerce and navigation of 1831. In the new treaty, he maintained that it had "the character of a practical law, agreed upon and established

${ }^{2}$ W. M. Malloy, Treaties, Conventions, etc. (Washington, 1910), I. 1112-1113.

3 Senate Ex. Doc. 1, 30th cong., 1st sess., p. 11; House Ex. Doc. 8, ibid., p. 55.

- Senate Ex. Doc. 52, 30th cong., 1st sess., p. 176.

s Ibid., p. 293. 
upon serious consideration of its requirements, and in the bona fide intention that these shall [should] be fulfilled". ${ }^{6}$

When Article XI. came up in the Senate it occasioned considerable debate. Attempts were made to strike out one paragraph after another until virtually the whole was embraced. Excepting the clause which made it unlawful for any inhabitant of the United States to furnish the Indians with firearms or ammunition, however, all these attempts failed. ${ }^{7}$ Secretary of State Buchanan, in a letter to the Mexican Minister of Foreign Relations, assigned a humanitarian motive for the Senate's action in regard to this clause. "This amendment was adopted on a principle of humanity. These Indians must live by the chase; and without firearms they cannot secure the means of subsistence. Indeed, for the want of such arms the extremity of hunger and suffering might drive them to commit the very depredations which the treaty seeks to avoid, and to make incursions for food either upon the Mexican or American settlements". ${ }^{8}$

In the same paragraph Buchanan asserted that his government possessed "both the ability and the will to restrain the Indians within the extended limits of the United States from making incursions into Mexican territories as well as to execute all the other stipulations of the eleventh article". During the next few years Mexican officials were to question the "will" and the United States was to have its eyes opened as to the "ability" required to restrain the Indians in question.

The Indians of the International Border.-There were in the territory acquired by the annexation of Texas and the treaty of 1848 some 160,000 Indians. ${ }^{9}$ By no means all of them were within reach of the Mexican border and a great number were semi-civilized or docile, but the wildest and most cruel habitually lived upon the fruits of the chase and upon plunder taken from the inhabitants of northern Mexico. The Apaches and Coman-

${ }^{6}$ Ibid., p. 293.

7 Ibid., pp. 11-13.

${ }^{8}$ Globe, 30th cong., $2 \mathrm{~d}$ sess., p. 494.

- Report of Commissioner of Indian Affairs, November 26, 1853, in House Ex. Doc. 1, part I, 33d cong., 2d sess., p. 243. 
ches, especially, and to a lesser degree the Utahs, Navajos, Kiowas, and Yumas, had been from Spanish times the terror of the northern frontier. ${ }^{10}$ These tribes, moreover, were often at war with each other and with the semi-civilized Indians, so that by the acquisition of the new territory the United States assumed the three-fold task of keeping them at peace with each other, protecting its own citizens from their outrages, and restraining the wild tribes from their accustomed depredations upon Mexico. This task was complicated and rendered more difficult by mountain, desert, and summer's heat, by Mexican sympathizers residing along the border and within the limits of the United States, by somewhat unscrupulous traders and "land-grabbers", by conflict between state and federal as well as civil and military authority and, finally, by lack of any agreement between the United States and Mexico for reciprocal crossing of the border in pursuit of the depredating bands. ${ }^{11}$

Congressional Action.- - In regard to the Indians of the Southwest, Congress, busy with quarrels over the status of slavery, was slow in forming a definite policy. Indeed a consistent policy was not pursued until after Article XI. had already been abrogated. At the close of the Mexican War there were in Texas one agent and two interpreters, ${ }^{12}$ while in New Mexico and California there was none. Eighteen months after the ratification of the Guadalupe Hidalgo treaty the Commissioner of Indian Affairs reported that, since Congress had failed to provide agents for the Indians of New Mexico and California, it had been necessary to appoint three sub-agents and to transfer two agents from the upper Missouri. This had been done with the obligations imposed by the late treaty with Mexico in mind. ${ }^{13}$ On September 30, 1850,

${ }^{10}$ Bancroft, North Mexican States and Texas (San Francisco, 1886-1889), II. 593 et seq; El Universal, June 3 and July 22, 1849.

11 Annie H. Abel, The Official Correspondence of James S. Calhoun while Indian Agent at Santa Fé and Superintentent of Indian Affairs in New Mexico (Washington, 1915), pp. 50-51, 250, 260, 379, 421-422, 431, 438, 445-455 passim; Senate Ex. Doc. 1,31 st cong., 2 d sess., p. $43 ;$ El Universal, January 13, 1853. The Indians of California, excepting those living near Yuma Junction, seem not to have made incursions into Mexico, and may therefore be disregarded here.

129 U. S. Statutes at Large, p. 204.

${ }^{13}$ Globe, 31st cong., 1st sess., opp., p. 27. 
$\$ 25,000$ were appropriated for treating with the Indians of California, two more agents and two more interpreters were authorized for Texas, and the sum of $\$ 30,000$ was set aside to meet the expense of procuring information and collecting statistics necessary to the Indian Bureau and for making treaties with and presents to the Indians of the United States upon the borders of Mexico. ${ }^{14}$ The work of the commission appointed under this bill was cut short, however, by the failure of Congress to make an appropriation for its continuance during the next year, and it disbanded in August, 1851, without having accomplished anything definite. ${ }^{15}$

During the discussion of this bill in the House, Congress was criticised for its dilatory policy. Representative Johnson of Arkansas said that although two years had elapsed since the peace with Mexico, this was the first step taken since then to obtain any knowledge of the newly acquired Indians, and that he considered it economy to spend $\$ 30,000$ for this purpose when a single incursion into Mexico might cost many times that amount. The bill was opposed on the ground that it would increase the number of public offices and consequently the executive patronage, and that the work could be done by the Indian agents or sub-agents, or by the members and escort of the commission authorized to survey the boundary between the United States and Mexico. ${ }^{16}$

In regard to the Indian affairs of the newly acquired domain, one of the crying needs was the extension to the tribes of Texas and New Mexico of the provisions of the law regulating trade and intercourse and preserving peace with the Indians. ${ }^{17}$ In his annual report for 1849, the Secretary of Interior had urged that Congress make some arrangement with Texas whereby the laws governing the natives might be extended to its territory. Until this had been done, he maintained that the efforts of his department to secure the extensive frontier from depredations, and to

${ }^{14} 9$ U. S. Statutes at Large, pp. 555-558.

${ }^{16}$ House Ex. Doc. 2, 32d cong., 1st sess., pp. 302-306.

${ }^{16}$ Globe, 31st cong., 1st sess., pp. 1515-1517.

${ }^{17}$ For this law, see 4 U. S. Statutes at Large, pp. 729-735. 
give the adjacent provinces of Mexico the protection stipulated by the treaty of 1848 would be in vain..$^{18}$ James S. Calhoun, Indian agent at Santa Fé, registered complaint after complaint against unscrupulous traders who not only inflamed the minds of the Indians against the authorities, but gave them firearms in exchange for plunder and captives taken from Mexico. ${ }^{19}$ The Mexican authorities likewise complained of traders and speculators who lived among the Indians of Texas and bought their spoils. $^{20}$ Yet it was not until February 27, 1851, that the desired regulations were applied to New Mexico ${ }^{21}$ and they were not extended to Texas until after the Gadsden treaty had relieved the United States from responsibility for the Indians under consideration.

Moreover, in Texas a somewhat peculiar situation arose from the fact that upon entering the Union that State retained control over its public lands. These had been surveyed and sold until the Indians had become alarmed lest none should be left for them, and had been made to feel that plunder was the only means of gaining a subsistence. ${ }^{22}$ In September, 1850 a bill to extend to Texas the benefits of the general act of 1834 regarding Indian affairs passed the Senate. After being given a second reading in the House it died, apparently, in the hands of the Committee on Indian Affairs. ${ }^{23}$ Indian Commissioner Luke Lea, in his annual report for 1850, expressed the opinion that the law of 1834 could not be applied to Texas without the consent of the legislature of that State. While Congress had power under the constitution to regulate trade with the Indians, yet there was a question in his mind as to whether that power could be exercised in such a manner as to punish the citizens of Texas for trespassing upon lands occupied by the Indians or trading with them without government license. Therefore, he urged that a commission

${ }^{18}$ Globe, 31st cong., 1st sess., opp., p. 23.

${ }^{19}$ Abel, Official Correspondence of James S. Calhoun, pp. 50-51, 105-106, 160-162.

${ }^{20}$ Mexican Border Commission of 1873, Report, p. 328; Senate Ex. Doc. 1, part II., 31st cong., 1st sess., pp. 20-23.

${ }^{21} 9$ U. S. Statutes at Large, p. 587.

22 House Ex. Doc. 1, part II., 32d cong., 2d sess., p. 35.

${ }^{23}$ Globe, 31st cong., 1st sess., p. 1727. 
be appointed to confer with Texas with reference to the adjustment of Indian affairs. ${ }^{24}$ On January 27, 1852, a bill bearing the same title as that of the previous September was introduced in the Senate and given the first and second reading but died in the committee room. ${ }^{25}$ In October, Major General Percifer F. Smith, commander of the United States forces in Texas, urged the necessity of immediate action in regard to Texan Indians so that some definite and determined policy might be pursued. Until such action was taken he declared he could not even tell the Indians what was expected of them. ${ }^{26}$ In his annual message, President Fillmore expressed the hope that Congress might induce Texas to set aside land for the Indians, otherwise the fulfilment of the treaty with Mexico and the duty of his government to the Indians would become a serious embarrassment. ${ }^{27}$ Yet, in spite of these efforts, arrangements for Indian reservations in Texas were not made until July, 1854. At this date, the permission of Texas having been previously granted, appropriations were voted for the selection and survey of suitable land and for the removal of the Indians thereto. ${ }^{28}$ In 1855 two colonies were established, one at the Brazos near Fort Belknap, and the other on Clear Fork about forty-five miles from its confluence with the main river. ${ }^{29}$

Meanwhile Congress had slightly loosened the purse strings. On February 27, 1851, an appropriation was made for four agents for New Mexico and one for Utah. ${ }^{30}$ In August of the following year $\$ 20,000$ were set aside for general Indian service in New Mexico, while $\$ 100,000$ were appropriated to Indians who had been deprived of lands in California. ${ }^{31}$ Finally the general appropriation bill which made provision for placing the Indians

${ }^{24}$ Senate Ex. Doc. 1, 31st cong., 1st sess., p. 44.

${ }^{25}$ Globe, $32 \mathrm{~d}$ cong., 1st sess., p. 389.

${ }^{28}$ House Ex. Doc. 1, part II., 32d cong., 2d sess., p. 15.

${ }^{27}$ Globe, $32 \mathrm{~d}$ cong., $2 \mathrm{~d}$ sess., p. 10.

2810 U. S. Statutes at Large, p. 331; Gammel, Laws of Texas (Austin, 1898) V. 51-52.

29 Bancroft, History of the North Mexican States and Texas, II., p. 406-487.

${ }^{30} 9$ U. S. Statutes at Large, p. 587.

3110 U. S. Statutes at Large, pp. 55-56. 
of Texas upon reservations, provided also for the segregation of the California Indians and set aside $\$ 65,000$ for dealing with those of New Mexico.

Congress likewise moved slowly in regard to meeting the needs of the military establishment of the country. Although that body increased by degrees the appropriations for, and the peace status of, the army, the increase was never commensurate with that requested by the President and the Secretary of War. Such an attitude may be explained largely by the agitated state of politics and a desire to economize. Debates upon bills for appropriations or increase of the army tended often to become discussions on the responsibility for the Mexican war, on slavery, or on other questions of party politics, and the Ways and Means Committee was inclined constantly to trim the estimates submitted by the War Department and supported by the Committee on Military Affairs.

The expense of maintaining the army during the period under consideration was considerably in excess of that for any peaceful period of equal length in the history of the nation up to that time, and the desire for its reduction was not circumscribed by party lines. Indeed, exasperated Whigs considered the new territory a white elephant on the government's hands and were not unwilling to return it to Mexico and even to give that country a few millions to take it back. ${ }^{32}$ The perplexing question was how to reduce the military expenses and at the same time not only protect the inhabitants of the new territory but restrain the Indians from incursions into Mexico.

Congress was late in making appropriations for the year ending June 30, 1849. In his message, communicated to the House on August 2, the President stated that he thought an increase of the army in excess of the provision of the act of May 13, 1846, unnecessary. That act provided that each company should be composed of sixty-four enlisted men and authorized the chief executive at his discretion to raise the number to one hundred. The appropriation bill which the Ways and Means Committee

${ }^{32}$ Globe, 30th cong., 1st sess., pp. 1032-1034, 1063. 
reported on the same day, however, contained a section repealing the act of 1846, thus placing the army on the peace status of 1842 , which would mean only forty-two men per company. The proposition received warm discussion. It was opposed on the ground that forty-two men per company would furnish only a little more than six thousand troops available for service, while the Secretary of War declared that he needed five thousand men for New Mexico and California alone. Robert McLane of Maryland proposed to meet the difficulty by authorizing a mounted regiment for the western frontier. Toombs of the Ways and Means Committee took a decided stand against a regular army, declaring that when the doors of the temple of Janus were shut the epaulets should be stripped from the army, and the soldiers and officers returned to their employment. Gentry of Tennessee and Barringer of North Carolina used our treaty obligations to Mexico as an argument in favor of increasing the military force. The bill as finally passed and approved (August 14, 1848) left the army with the peace standing of 1842 , but gave the President power to increase five regiments, by transfers from other regiments, to such a number as he deemed wise, "not exceeding one hundred privates". ${ }^{33}$

During the second session of the Thirtieth Congress there was manifested the same desire to decrease the military expenses of the country. When the general army appropriation bill came up for consideration, Mr. Greely of New York objected strenuously to the amount set aside for recruiting and to the quantity of expenditures on the army and navy in general, contrasting them with the former expenditures of the nation. He lauded England's policy of pacifying the Indians of Canada, and declared that if the government of the United States were to spend more money in order to maintain peace among the Indians, the standing army could be reduced, and the frontiers could be defended by a volunteer army. In the discussion of the bill the slavery issue was often interposed..$^{34}$

\footnotetext{
${ }^{33}$ Globe, 30th cong., 1st sess., pp. 1024-1036, 1063, 1072; 9 U. S. Statutes at Large, p. 306. This bill, as indeed most of the army appropriation bills of this period, received little discussion in the Senate.

${ }^{34}$ Globe, 30th cong., 2d sess., pp. 123, 350-351, 366-367, 371.
} 
The Thirty-first Congress passed not only the largest single army appropriation bill of the period in question but also another measure of considerable importance to the frontier. Yet there was manifested vigorous opposition to increase of expenditures. A bill to "increase the rank and file of the army and to encourage enlistments" was introduced in the House on February 26, 1850, where it received its warmest discussion on May 23. Its supporters used two main arguments: the perilous condition of the western frontier; and treaty obligations to Mexico under the eleventh article of the treaty of Guadalupe Hidalgo. Its opponents either maintained that the present army was sufficient or favored the substitution of volunteers for regulars. Representative Harris of Illinois, proposed the raising of 1200 mounted rangers for a year, while Representative Howard of Texas was in favor of enlisting two regiments of rangers to be continued in service so long as the public defense required. The inadequacy of infantry for frontier defense was clearly set forth, but when the bill was under consideration in the Senate, Rusk of Texas opposed the clause authorizing the mounting of the infantry. $\mathrm{He}$ was thoroughly convinced that infantry was "worse than useless" on the frontier, but he did not think that cavalry could be made out of men who neither knew how to ride nor to care for their horses. He was in favor of raising more cavalry and declared that treaty obligations to Mexico were being "violated every day". In its final form, the bill contained three provisions which related primarily to the Indian problem: 1 . The President was authorized to increase the size of any company serving then or thereafter on the western frontier or at distant military posts to a number not exceeding seventy-four. 2. He was given power at his discretion to mount companies of infantry. 3 . Recruits enlisted in the vicinity of the frontier posts were to be allowed a bounty equal to the price of transportation and subsistence of a soldier from the Harbor of New York to the place of such enlistment: ${ }^{35}$ The appropriation bill gave the commis-

${ }^{35}$ Globe, 31st cong., 1st sess., pp. 1049-1051, 1059-1060, 1180-1181; 9 U. S. Statutes at Large, pp. 438-439. 
sioned officers of Oregon and California $\$ 2.00$ per day extra and enlisted men double pay. ${ }^{36}$

At the second session of the Thirty-first Congress an even more determined effort was made to cut down the soaring estimates of the War Department. That department desired nine million dollars, but the Ways and Means Committee reduced the sum to seven and one-half millions. Toombs of the committee declared that, while the estimates for 1840 allowed $\$ 404$ per year for each man in the service, those for 1851 required $\$ 900$. He said the people of the frontier were desirous of defending themselves and he was in favor of allowing them to do it. Mr. Howard, representative from Texas, revealed the fact that Mexico had again urged the subject of Indian depredations upon the United States, and censured the government of the United States for opposing the calling out of rangers. Members of the military committee undertook to explain the high estimates of the War Department. The cost of forage and of transportation to the frontier posts was very high. Supplies for New Mexico had to be carried 820 miles across the country from Fort Leavenworth, Missouri, and transportation to Texas was expensive. Rations for a soldier at the Texan posts cost nineteen cents per day while those of a soldier of New Mexico cost forty-two cents. The Quartermaster's Department alone spent four million dollars during the year ending June 30, 1851. Yet for all this expense the frontier was insecure and the House was warned that Mexico would be demanding indemnities. Congress failed to provide additional cavalry, however, and the appropriation was left at slightly over seven and one-half millions, only to be supplemented later by a deficiency bill of more than two millions. ${ }^{37}$

Finally, during the Thirty-second Congress, an attempt was made to obtain an appropriation for trying out camels on the western desert, and distributing arms to the citizens of Utah, Oregon, New Mexico, California, and Texas, while at the same

36 Ibid., pp. 504-505.

${ }^{37}$ Globe, 31st cong., 2d sess., pp. 523, 581, 702-706, 721-728; House Journal, pp. $288,395,450 ; 9$ U. S. Statutes at Large, pp. 618-621; 10 U. S. Statutes at Large, pp. 16-17. 
time it was proposed to authorize the President to call out the militia and to accept the service of volunteers. The provision for testing the efficiency of camels was offered as an amendment to the general appropriation bill. The other proposition was purported to have come as a recommendation from the President, the Secretary of War, and Colonel Sumner of New Mexico. During its discussion facts were brought out which showed that New Mexico and the frontiers of Texas were in a terrible condition. The measure passed the House, but, when returned by the Senate, it contained amendments to which the House objected and, consequently, failed to pass. ${ }^{38}$

The Work of the Indian Department.-While Congress was proceeding in this dilatory fashion, the Indian Department was working with what means it could obtain, and with the treaty obligations to Mexico in mind. On April 7, 1849, Calhoun was made Indian agent for New Mexico and instructed, among other things, "to determine the number of prisoners held by the Indians in that territory, whether they were Americans or Mexicans and, if Mexicans, whether they were taken prior to the termination of the war and treaty with Mexico, or subsequently". ${ }^{39}$ Calhoun arrived at his post on July 22; and for the next three years, first as agent, and then as Governor and Superintendent of Indian affairs, he labored arduously and conscientiously, but was always greatly handicapped for lack of means and equipment. In the spring of 1849 , J. C. Hays had been sent to the Gila Apaches, but in January of the following year he had resigned his post declaring his "inability to be of any service whatever with the means furnished". 40 Early in 1850, Calhoun took the liberty of sending Cyrus Choice as agent among the Utahs, with the hope of obtaining means for paying him by a later appropriation. ${ }^{41}$ Other than these he seems to have had no assistance until the four agents appointed by the law of February 27, 1851, arrived.

\footnotetext{
${ }^{38}$ Globe, 32d cong., 1st sess., pp. 1442*-1444*, 1457-1459, 1594, 1789-1791, 1870, 1883, 1909-1915.

${ }^{39}$ Commissioner of Indian Affairs to Calhoun, April 7, 1849, in Abel, Official Corespondence of James S. Calhoun, pp. 3-5.

${ }^{40}$ Ibid., p. 34, note.

11 Ibid., pp. 122, 142-143, 187.
} 
It does not fall within the scope of this paper to follow the details of the labors of these Indian agents. We are concerned here primarily with their attempts to carry out the provisions of Article XI. An examination of their work will reveal considerable effort to meet this responsibility. During the period of their service prior to December 30,1853, when negotiations for the Gadsden Treaty were completed, four important Indian treaties were made, three of which were ratified by Congress. Each contained the stipulation that the Indians should deliver up Mexican prisoners. The treaty with the Gila Apaches (July 1, 1852) went a step further and pledged the Indians in the future to desist from making incursions of a hostile or predatory character into the territory of Mexico and to refrain from taking captives therefrom. ${ }^{42}$

Moreover, on at least three occasions Calhoun reported that prisoners taken from the Indians of New Mexico had been handed over to the Mexican authorities. On June 27, 1850, thirteen Mexican captives were given to José N. Prieto at El Paso. ${ }^{43}$ On August 5, 1851, five more were delivered at the same place and, later in the month, Calhoun reported that three others were being held awaiting the disposal of the Mexican government. ${ }^{44}$ As it was wellknown that the Gila Apaches had numerous Mexican prisoners ${ }^{45}$ it is not unlikely that after the treaty of July, 1852, these also were sent to their homes. This much at least was accomplished by the Indian agents of New Mexico-a not inconsiderable task when the difficulties under which they labored are borne in mind.

The efforts of the Indian agents in Texas were perhaps not so fruitful in tangible results. This was likely due to the want of close coöperation owing to the fact that there was no superintendent of Indian affairs in Texas, as well as to the great difficulties arising from the lack of a definite policy. The time of the

${ }^{2}$ Kappler, Laws and Treaties (Washington, 1904), II. 585-586, 598-600; Abel Official Correspondence of James S. Calhoun, p. 314-316.

${ }^{43}$ Abel, Official Correspondence of James S. Calhoun, p. 227.

14 Ibid., pp. 390, 401.

${ }^{46}$ Ibid., p. 401. 
agents was chiefly occupied in distributing rations from the various posts on the frontier and in pacifying the Indians in regard to their lands. ${ }^{46}$ By the treaty of 1846 , the leading tribes of Texas agreed to surrender "all white persons and negroes" whom they captured. ${ }^{47}$ Lieutenant Colonel Hardee reported in August, 1851, that the Comanches and Lipans had handed over seventeen Mexican captives to Judge Robbins [Rollins], one of the special Indian agents of Texas, and that they had been restored to their families. Hardee stated that these were the "only Mexican prisoners delivered up by the Indians since the establishment of the eighth military department". ${ }^{8}$ No further instance of the return of prisoners by the Texan agents has been found.

Finally, on July 27, 1853, Special Agent Thomas Fitzpatrick negotiated at Fort Atkinson a treaty with the Comanches, Kiowas, and Apaches, the fifth article of which bound these tribes to refrain in the future from warlike incursions into the Mexican provinces and, not only to restore all captives who might be taken by "any bands, war-parties or individuals of said several tribes", but to make restitution for all wrongs inflicted upon Mexicans. ${ }^{49}$

In general, however, these treaties were not adhered to with any degree of faithfulness, and to the conciliatory negotiations of the agents it was necessary to add the chastisements of the army.

Number and Location of the United States Troops on the Mexican Border.-In the distribution of the troops on the southwestern frontier fulfillment of treaty obligations to Mexico seems to have been kept in mind. The Secretary of War in informing General Brooke of his appointment as Commander of the Eighth Military Department urged him to make earnest efforts to reclaim and restore all captives who had been taken and carried away by the Indians. "This duty", he continued, "has been assumed in behalf of the Mexican people by a treaty with Mexico, which is con-

${ }^{46}$ House Ex. Doc. 5, 31st cong., 1st sess., pp. 963-965. House Ex. Doc. 2, 32d cong., 1st sess., pp. 515-526; Senate Ex. Doc. 1, 32d cong., 2d sess., pp. 431-436.

47 Kappler, Laws and Treaties, II. 554.

48 Hardee to Deas, August 29, 1851, House Ex. Doc. 2, 32d cong., 1st sess., pp. 121-122.

10 Kappler, Laws and Treaties, II. 600-602. 
sidered as superadding only a specified obligation to the general claim which humanity imposes on all civilized nations". ${ }^{50}$ On February 3, 1849, Washington, of New Mexico, wrote AdjutantGeneral Jones that he had neglected nothing to effect a speedy release of prisoners in accordance with the treaty of 1848 . Many had been restored to their homes in New Mexico, and others were awaiting instructions from the Mexican republic. ${ }^{51}$ In his annual report for 1849 , the Secretary of War stated that military operations in Texas and New Mexico had resulted in the recovery of numerous captives, several of whom had been returned to their homes. ${ }^{52}$

Again, in the spring of 1851, when new commanders were sent to Texas, California, and New Mexico, respectively, each of them was given specific instructions regarding the organization of his department. In establishing military posts they were to be governed by three principles, one of which was the protection of Mexico from the raids of hostile Indians. The letters contained a complete statement of the Secretary's views in regard to the matter. He ordered those officers to "bear in mind that the Mexican territory is as much entitled as our own to the protection of our troops against Indian tribes within our limits". ${ }^{53}$

The great need of the frontier was efficient soldiers. The Adjutant-General's report of December 2, 1848, showed a total of 616 troops, rank and file, at the New Mexican posts while 322 more were en route. According to the same report, Texas had 787 rank and file present, with 575 en route. At the close of the next year, there were only 708 rank and file present in New Mexico, while there were 1,074 in Texas. These troops were gradually increased until, in 1853 , there were 1,407 , including officers, in New Mexico, and 2,649 in Texas. Adding to these the 114 stationed at Fort Yuma, there would be a total of some 4,100, rank

${ }^{50}$ Crawford to Brooke, June 4, 1849, House Ex. Doc. 5, 31st cong., 1st sess. pp. 138-139.

${ }^{51}$ Ibid., p. 105.

52 Ibid., p.94.

${ }^{63}$ Secretary of War to Smith, April 30, 1851, House Ex. Doc. 2, 32d cong., 1st sess., p. 117 ; Ibid. to Sumner, April 1, 1851, Ibid., p. 125 ; Ibid.to Hitchcock, May 3, 1851, Ibid. p. 143. 
and file, stationed within reach of the Mexican frontier, though they were by no means all sufficiently close for immediate service. The only portion of this force which could be considered really effective against Indians, who were usually well-mounted and always excellent horsemen, was the cavalry. In this respect, however, the frontier force was weakest. During this period, from the mouth of the Rio Grande to El Paso, no cavalry was stationed on the immediate border. Beginning with 1849, dragoons were posted some distance back of the line, about forty or fifty having been stationed in that year along with the infantry at Fort Inge and Fort Martin Scott. They remained at the latter post till 1851 and at the former till 1852. Beginning with 1852 , more than two hundred mounted riflemen were posted at Forts Inge, Ewell, and Merrill-a number increased to 325 in 1853; and in the latter year, some fifty dragoons were stationed at Fort Terrett. Above El Paso at Socorro, some thirty-five or forty dragoons were stationed during the years 1848, 1849, and 1850 , and probably a few more than this number at Doña Ana during the latter two years. Beginning with 1851, an average of about eighty dragoons were stationed at Fort Fillmore, and almost an equal number were at Fort Webster in 1852 and 1853. Therefore, not more than 180 mounted men were within immediate reach of the frontier at any one time during the period 18481852 , and never more than six hundred at any time during the entire period. ${ }^{54}$

The regulars were often supplemented by volunteer companies. Following a severe raid on Corpus Christi in the late summer of 1849, three companies of mounted militia were called into service. In March of the following year, the Governor of Texas was called upon for another company. These four were retained in service until fall. ${ }^{55}$ During the spring and summer of 1851

${ }^{54}$ See Reports of Adjutant-General, 1848-1853, in House Ex., Doc. 1, 30th cong. 2nd sess., p. 184; Senate Ex. Doc. 1, 31st cong., 1st sess., p. 188; Senate Ex. Doc. 1, part II., 31st cong., 2d sess., p. 116; House Ex. Doc. 2, 32d cong., 1st sess., pp. 200206 ; Senate Ex. Doc. 1, 32d cong., 2d sess., pp. 58-60; Senate Ex. Doc. 1, 33d cong., 1st sess., pp. 118-121.

${ }^{55}$ House Ex. Doc. 5, 31st cong., 1st sess., pp. 148-150; Senate Ex. Doc. I, part II., 31st cong., 2d sess., p. 31 ; House Ex. Doc. 1, part II., 32d cong., 2 d sess., p. 16. 
volunteer companies under McCullock, Wallace, Connor, and Ford were kept in the field. ${ }^{56}$ In response to a call issued by Governor Washington of New Mexico, March 20, 1849, four companies, one of infantry and three of cavalry, were mustered into service. ${ }^{57}$ Among the force which proceeded against the Apaches from Rayado, in July, 1850, were ninety Mexican volunteers, citizens of New Mexico. ${ }^{58}$ Probably there were other instances when militia was used, but there was always the expense objection, and early in 1852 considerable suffering resulted in New Mexico because the poverty of the territorial government would not permit the purchase of arms and ammunition, and the Governor neither had power to call out the militia nor the ability to persuade the commander of the ninth department (New Mexico) to furnish army supplies..$^{59}$ The President had authority after 1850 to mount the infantry when occasion demanded, but such improvised cavalry was necessarily inefficient.

Failure of the United States to Protect the People of Texas and New Mexico.-Indeed, the military forces, assisted by the Indian Department, when the two could work in harmony, were admittedly and decidedly unable to cope with the Indian situation. The secretaries of War and Interior constantly complained of the inadequacy of the resources placed in their hands, ${ }^{60}$ and the citizens of Texas and New Mexico lamented their perilous condition while they memorialized the government. A joint resolution of the Texan Legislature (January 28, 1850), in urging their representatives to lay the matter before Congress, declared that "vast numbers" of citizens had been captured and killed and property, "to a vast amount", had been stolen and carried away by the Indians. ${ }^{61}$ A petition, dated at Santa Fé, February 27, 1850, and signed by fifty-two citizens, asserted that although some of the

${ }^{56}$ Globe, 32d cong., 2d sess., pp. 1909-1915.

${ }^{67}$ House Ex. Doc. 5, 31st cong., 1st sess., pp. 107-110.

${ }^{68}$ Senate Ex. Doc. I, part II., 31st cong., 1st sess., p. 74.

${ }^{59}$ Abel, Official Correspondence of James S. Calhoun, pp. 366, 473, 480, 507.

${ }^{50}$ See Reports of 1850, 1851, in Senate Ex. Doc. 1, 31st cong., 2d sess., p. 19; Ibid., part II, p. 3 ; House Ex. Doc. 2, 32d cong., 1st sess., p. 105; Ibid., part II., o. 489 .

s1 Gammel, Laws of Texas, III. 85. 
petitioners had lived in Mew Mexico from five to fifty years, they had never known Indian troubles to be as terrible and alarming. ${ }^{62}$ Petitions of a similar nature were presented in the summer of the following year. ${ }^{63}$ General Brooke of Texas said in 1851, that he needed three thousand cavalry for his department, while McCall of New Mexico asked for fourteen hundred. ${ }^{64}$ So far as the Texans and New Mexicans were concerned, the Indians were reported quiet in $1852,{ }^{65}$ but during this very time their raids upon Mexico were particularly destructive. ${ }^{66}$

The Indian Policy of Mexico.-Officials of the United States were inclined at times to accuse the government of Mexico of failing to coöperate with them in the pursuit of Indians, while making attempt to defend itself from their incursions. ${ }^{67}$ The facts, however, will hardly bear out the correctness of this view. Indeed, Mexico made a special effort during this period to provide for the protection of the northern frontier, and failure was due to lack of means, internal disturbances, and filibuster raids, rather than to indifference.

By special law of December 4, 1846, designed to direct colonization, a provision had been made for establishing "military colonies, composed of Mexicans or foreigners, or of one or both, along the coasts and frontiers as the government shall designate, especially in order to restrain the irruptions of the savages". ${ }^{68}$ A decree dated June 19, 1848, called attention to the fact that the frontier line as marked by the late treaty with the United States demanded urgent attention in order to conserve the integ-

62 Abel, Official Correspondence of James S. Calhoun, p. 157.

${ }^{63}$ Ibid., pp. 366-386.

${ }^{64}$ Globe, 31st cong., 2d sess., p. 722.

${ }^{65}$ Abel, Official Correspondence of James S. Calhoun, pp. 529, 540; Report of the Secretary of War, in House Ex. Doc. 1, 32d cong., 2d sess., p. 3.

${ }^{66}$ Mexican Border Commission, Report, 1873, pp. 292, 332; John Bartlett, Personal Narrative of Explorations and Incidents in Texas, New Mexico, California, Sonora and Chihuahua (New York, 1854), II. 385; El Universal, August 18, and November 17, 1852; Pinart Transcripts, Sonora, V. 1-135.

${ }^{67}$ Report of the Secretary of War, in House Ex. Doc. 2, 32d cong., 1st sess., p. 106; "Fillmore's Annual Message", House Ex. Doc.1,32d cong., 1st sess., pp. 1819; Globe, 33d cong., 1 sess., pp. 1534-1548.

${ }^{68}$ Francisco F. de la Maza, Código de colonización y terrenos baldios de la República Mexicána (Mexico, 1893), p. 356. 
rity of the nation's territory and "to defend the frontier states from the frequent and cruel incursions of savages", and proceeded to provide for the establishment of military colonies. The northern frontier was marked out into three divisions, designated as the Frontier of the East, the Frontier of Chihuahua, and the Frontier of the West, and eighteen colonies were distributed among them. Seven were allotted to the East, which included Tamaulipas and Coahuila, five to Chihuahua, another five to Sonora, and one to Lower California. The land around each colony, after being divided into lots and improved at government expense, was to be assigned to the soldiers for cultivation. Voluntary enlistment for a term of six years was provided, at the end of which time each soldier was to receive a bounty of ten pesos and the allotment of land which he had been cultivating. During his term of service he was to share the fruits of the soil. Provision was made for civilian settlers around each colony which upon attaining a certain population, was to receive a civil government. In the eighteen colonies, troops to the number of 2,426 were to be stationed, consisting of 1,715 cavalry and the rest infantry, and each cavalryman was to be equipped with two horses. ${ }^{69}$ This last provision is of especial interest when the proportion of cavalry which the United States provided for the frontier is considered.

In the course of the next three years these colonies were laid out either at the points designated or provisionally in places as near as the Indian situation would permit. The report of the Minister of War and Marine for 1850 states that in Chihuahua the colonies of Del Norte and El Paso del Norte were established in May and June, 1849, while those of San Carlos and Pilares were planted in May and July of the following year. Janos had not been established in the place determined, but preparations for it were being made. On the frontier of the East, the colonies of Rio Grande, Guerrero, Monclova-Viejo, and Monterey had been set up, but Camargo was yet unfounded, and the colony of San Vicente had been left provisionally at Santa Rosa. None of the colonies of the West had been established in their ultimate

${ }^{69}$ Ibid., pp. 400-406, Doc. 2. 
destinations, although 225 soldiers and 200 civilians were stationed at the ancient presidio of Fronteras and other soldiers intended for the colonies were campaigning against the Indians. During the following year, however, all the colonies were set up either permanently or provisionally. ${ }^{70}$

At the close of 1850, there had been recruited for the Colonies of the East 434 soldiers and 972 horses, for those of Chihuahua, 296 soldiers and 220 horses, for those of the West, 240 soldiers and 306 horses. By the end of the next year the force had increased to 502,334 , and 445 respectively, but there had been a falling off of almost 200 in the number of horses, while the report of December, 1851, showed a decrease in both stock and men, there being in all the colonies at that time 1,093 soldiers and 689 horses and mules. ${ }^{71}$

By treaties of October, 1850, and July, 1852, peaceful Seminoles and Muskogees had been permitted to settle in the vicinity of the colonies of the East and of Chihuahua. ${ }^{72}$ In 1851, reduced

70 The situation of the military colonies in 1851 is given as follows:

1. Camargo, in the town of that name.

2. El Pan, at Lampazos.

3. Monterey, at Paso de Piedra.

4. Rio Grande, at Mision Nueva.

5. Guerrero, at Piedras Negras.

6. Monclova-Viejo, at Moral.

7. San Vicente, in the old presidio of Agua Verde.

8. San Carlos, in the old presidio of that name.

9. Del Norte, at Presidio del Norte.

10. Pilares, in Vado de Piedra.

11. Paso, about fourteen leagues down the Rio Grande from El Paso.

12. Janos, near the village of Janos.

13-17. The five colonies of Sonora, at the presidios of Bavispe, Fronteras, Santa Cruz, Tucson, and Altar.

18. Rosario, at Mision Santo Tomás in Lower California.

See Manero, Documentos Sobre colonización, pp. 28-36.

"1 Ministerio de Guerra y Marina, Memoria, January, 1850, Doc. 4; January, 1851, Doc. 1; December, 1851.

72 Mexican Border Commission of 1873, Report, p. 304; Ministerio de Guerra y Marina, Memoria, December 31, 1851, in Vicente L. Manero, Documentos sobre colonización (Mexico, 1878), p. 30. A. M. Jauregui, Inspector of the Colonies of the East, had written in regard to the matter in July, 1850, and a decree of November 18, 1850, had stated the conditions under which they were to be received. Maza, Código de colonización, pp. 474-475. 
Sierra Gorda Indians were sent to augment the frontier forces. In March, 1853, General Blanco, the new inspector, arrived in Sonora with resources sufficient to place 1,500 men under arms, and during the same year, a French colony, accepting privileges extended in accordance with article 45 of the decree of 1846 , settled at Cocóspera. ${ }^{73}$

Besides these military colonies a considerable number of regulars was stationed in the frontier states; and in 1849, following out the recommendation of a junta of the Federal Congress formed for the purpose of considering means of frontier protection, an appropriation was made for raising 4,000 national guards..$^{74}$ Moreover, the towns of the afflicted sections formed leagues for common defense; private individuals contributed to war and ransom funds; Durango, Chihuahua, and Sonora offered bounties for scalps and prisoners, and, finally, the frontier States of Nuevo León, Chihuahua, Coahuila, Zacatecas, Tamaulipas, and San Luis Potosí began (1851) plans for union to resist the common peril. ${ }^{75}$

These measures were rendered ineffective, however, by internal disturbances and the chaotic state of the national funds, by the poverty of the frontier states, by epidemics of cholera and fever, by the quest for gold which drew a large number of Sonorans annually to California and, lastly, by the filibusters who, beginning their raids in 1851, kept the whole northern border in almost constant agitation. ${ }^{76}$ Taking such difficulties as these into consideration, one will hardly be surprised to learn that the

${ }^{73}$ Pinart Transcripts, Sonora, V. 2, 8, 11. By decree of May 20, 1853, Santa Anna seems to have incorporated the military colonies with the milicia activa. Manuel Dublan and José Maria Lozano, Legislación Mexicana (Mexico 1876-,) VI. 407,412 .

${ }^{74}$ Legislación Mexicana, pp. 551-552.

${ }^{75}$ Mexican Border Commission of 1873, Report, pp. 273, 298, 340; Pinart's Transcripts, Sonora, IV. 188, 215-216; Bancroft, History of Mexico, V. 579-580.

${ }^{76}$ Mexico, Documentos relativos a la reunion en esta capital de los gobernadores de los Estados convocados para proveer a las exigencias del erario federal (Mexico, 1851), pp. 2-52; Bancroft, History of Mexico, V. 603-605, 685-686; Pinart Transcripts, Sonora, IV. 86-87, 264, 273, 283; Ministerio de Guerra y Marina, Memoria, 1850, pp. 14-15; Senate Ex. Doc. 97, 32d cong. 1st sess., pp. 89, 113. 
number of troops of all classes on the northern frontier was only 2,136 at the close of 1849 , and 3,189 in January $1851 .{ }^{77}$

Only so much of the operations of the Mexican troops against the Indians as is necessary to convey a correct general idea of the attempts of that country to defend itself will be given. Tables compiled by the Mexican Commission sent to the border in 1873 show that the forces in Nuevo Leon had thirty-three encounters with the Indians from 1848 to 1853 inclusive, while those of Coahuila had more than forty. Files of El Sonoriense mention some thirty or forty in Sonora from 1848 to the beginning of the filibuster raids in September, 1851. Data as to the exact number of campaigns and skirmishes in the other states have not been ascertained, but it is safe to say that they were proportionately numerous. ${ }^{78}$ Indeed the federal government had adopted the policy of war to the death and favored an arrangement whereby the boundary of the United States could be crossed in pursuit of the depredating bands. ${ }^{79}$

Indian Raids upon Mexico, 1848-1853.-An attempt to ascertain the effectiveness of these encounters would be uninteresting and perhaps meager in results. It is not necessary, however, to go into this matter, for our purpose is only to determine whether Mexico in good faith endeavored to defend itself. The best proof of the failure of both the United States and Mexico in dealing with the Indian situation is found in the losses sustained by the latter during the five years under consideration. Indian incursions from 1848 to 1853 were destructive and frequent as far down the Mexican border as Reynoso in Tamaulipas. They increased in severity further north and west, assuming enormous proportions in Sonora; and they not infrequently extended to Durango, Zacatecas, and San Luis Potosí. ${ }^{80}$ The commission of

\footnotetext{
${ }^{77}$ Ministerio de Guerra y Marina, Memoria, January 24, 1850, Doc. 4; Ibid., January 3, 1851, Doc. 1.

78 See Mexican Border Commission of 1873, Report, pp. 253-281; files of El Universal, 1850-1853, Informe de la Comisión Pesquisidora de la Frontera del Norte (Mexico. 1874), Apéndice I-XLI; Pinart Transcripts, Sonora, vols. IV-V.

${ }^{79}$ Ministerio de Guerra y Marina, Memoria, 14.

${ }^{80}$ For Durango, see files of El Universal, 1849-1853. For Zacatecas and San Luis Potosi, see Mexican Border Commission of 1873, Report, pp. 337-340.
} 
1873 gave fairly complete reports for Nuevo León and Coahuila and a general discussion of 'Tamaulipas, San Luis Potosí, and Zacatecas, respectively, during the five years subsequent to the treaty of Guadalupe Hidalgo. As a basis for their statements they relied upon the testimony of witnesses and data found in the various archives of the region.

Discussion of Tamaulipas was confined chiefly to its five leading frontier towns. The first invasion of Reynoso took place in April, 1849, when a cattle station was assaulted, two persons killed, and four made prisoners. Three more incursions occurred during the course of the year and a number of cattle were stolen and driven across the river. There seems to have been no other invasion of this town until 1856. In Camargo, two raids were mentioned in 1849 , three in 1851 , and one in 1853 , though the extent of the damages was not stated. The archives of Mier were incomplete, but from them it was ascertained that there were four invasions in 1848 which resulted in the murder of five persons and the capture of six, together with the theft of all the horses that the Indians could find. For each of the next four years the Commission did not give the specific number of invasions. It mentions, however, "daily outrages" in which a "large number" of lives were lost and "numerous" captives taken. Likewise, the Commission failed to give a complete statement of the victims resulting from the Indian raids upon Guerrero, but it declared that the magnitude of the losses was astonishing and that there was not a single year in which murders did not occur. The President of the City Council was quoted as saying in a letter of November 23,1850, that within six days there had been "three killed and two dangerously wounded, in addition to the horses and mules carried off by the wretches", and again, in 1851, as informing the government that from January to the end of July, the Indians had "killed more than twenty townspeople". Finally, only a general statement is given concerning Nuevo Laredo, while an idea of the perilous condition of that town is conveyed by the assertion that it had been "surrounded daily and nightly by the Indians" and "all the horses there were in the neighborhood" had been stolen. ${ }^{81}$

${ }^{81}$ Mexican Border Commission of 1873, Report, pp. 225-281. 
With regard to the depredations on Nuevo León a more complete statement is given. Comanche incursions upon this state in 1848 resulted in the death of eleven persons, while three were wounded and two captured and droves of horses and mules were carried off. The next year the same tribe made thirty-four invasions, "killing thirty-four persons, wounding fourteen and capturing four, while the usual number of horses was seized. In 1850 , there were eighty-six incursions upon sixteen towns of the state with a toll of twenty-one deaths, twenty wounded, and four captives, besides the theft of more than a thousand animals. Notwithstanding vigorous efforts on the part of Nuevo León to meet the situation, the losses for the next year were "thirty-six killed, thirty-three wounded, and twelve captives, besides about three hundred horses", while in 1852 they were more numerous than ever. The casualties during this year amounted to sixtytwo killed, thirty wounded, and sixteen captives. Finally, there were seventy-seven incursions in 1853, causing a loss of thirtyfive killed, twenty-three wounded, and six captives, together with numerous horses and mules. ${ }^{82}$

Coahuila seems to have been damaged comparatively little by the Indian raids which occurred in 1848 , but during the four sub- . sequent years, that state suffered more than Nuevo León or Tamaulipas. From 1849 to 1853 inclusive, depredations which were committed both by the Comanches and the Apaches resulted in one hundred and ninety-one deaths, while one hundred and twenty-one were wounded and sixty-three captured, and considerable property destroyed and stolen. Indeed the Indians raided all parts of the state holding the people in almost constant peril of their lives. ${ }^{83}$

For the outrages committed in Chihuahua, files of El Universal, a paper printed in Mexico City, have been consulted. Although that organ made no attempt at a statistical summary of the losses or a complete statement of the raids, enough is given to

82 Mexican Border Commission of 1873, Report, pp. 288-319.

${ }^{83}$ Ibid., pp. 319-337. Tables in the appendix of the report in Spanish differ from these estimates in slight details. See Informe de la Comision Pesquisidora, Apéndice, II-XII, XXVII-XXXVII. 
reveal something of the perils suffered. ${ }^{84}$ Under date of June 2, 1849 , it was stated that a more bloody war than ever was being waged by the Indians of the northern frontier and that among the Chihuahuenses the main question was not one of politics or administration but of "living or perishing ingloriously at the hands of the barbarians". In an editorial of August 30, the same paper after picturing in vivid manner the infinite misfortunes suffered from Indian depredations, mentions Chihuahua as one of the states "suffering constantly". José Cordero (presumably a citizen of the state) in a pamphlet, published March 23, 1850, and urging the State Congress to adopt a plan of action against the Indians declared that the Apaches had killed hundreds of victims in the state and destroyed the fortunes of its inhabitants and were at that time planning greater destruction. ${ }^{85}$ On April 3, 1851; a Chihuahuan periodical was quoted to the effect that two thousand Indians were being fed at state expense in an effort to keep peace, the flocks were all destroyed, and the state whose evils exceeded its resources was seeking the protection and aid of the central government. In August of the following year it was stated that Indian incursions were a matter of daily occurrence, the number of their victims constantly increasing. Yet, in the midst of this peril, the Governor was spending his time publishing a manifesto against the Comandante, the Inspector of the Military Colonies, and the general government. ${ }^{86}$ In the latter part of the same year the permanent deputation of Chihuahua reported that, since the Comanches committed their crimes while passing through that state on their way to and from $\mathrm{Du}$ rango, their hostilities were of a minor character, but the Apaches were the terrible enemies which "daily" afflicted Chihuahua, carrying that state rapidly to its veritable "desolation". ${ }^{87}$ Successful campaigns waged against the Indians during the winter of

${ }^{84}$ The citations which follow could easily be multiplied.:

${ }^{85}$ El Universal, June 1, 1850.

${ }^{86}$ Ibid., August 18, 1852.

${ }^{87}$ Ibid., November 17, 1852. 
1852-1853 inclined them to sue for peace, but after a brief respite, they seem to have resumed their accustomed cruelties. ${ }^{88}$

The state which suffered most from Indian raids was Sonora. Our authority for the number and severity of these raids consists of transcripts from files of $E l$ Sonoriense. a Sonoran newspaper, and other documents of the Pinart Collection. ${ }^{89}$ These sources make no claim to be a complete statement of injuries, and often make such references as "numerous victims", or "many dead and wounded", without giving a specific statement as to the number. Leaving out of consideration all references of such general nature, a careful computation has given the following results.

In 1848, Moctezuma, Tubac, Santa Cruz, Fronteras, and Tumacacori, together with adjacent sections, all suffered from Apache raids which resulted in at least forty-six deaths, and Governor Gandara in his message to Congress, September 18, declared that depredations had assumed such proportions that there was no longer any safety on the highways. ${ }^{90}$

The year 1849 opened with several terrible raids which ex-. tended as far south as the vicinity of Ures. From January 10 to 23, eighty-six persons were killed and sixteen wounded, while during the whole of the year the Indians levied a toll of one hundred and eighty-one killed, thirty wounded and fifty-five captives. Few towns in the state escaped being ravaged, but the principal sufferers were Alamos, Tepachi, Bocoachi, Batuc, San Pedro, Banamichi, Bavispe, Santa Cruz, Bozatán and adjacent sections.

Peace negotiations continued throughout the following spring and during the fall vigorous campaigns were waged. Yet, according to reports, one hundred and eleven Sonorans were killed, thirteen wounded, and ten captured, while, in 1851, notwith-

${ }^{88}$ El Universal, November 25, December 10, 21, 24, 28, 1852, January 13, February 6, May 4, May 10, June 28, 1853.

${ }^{89}$ The title page of these manuscripts which consist of six volumes reads as follows: Documents for the History of Sonora. Extracts from MSS. and printed matter in the collection of Mons. Alphonse Pinart. Most of the extracts are in English and they cover the period of Sonoran history from 1781-1863. There are also two volumes dealing with Chihuahuan history.

- Pinart Transcipts, Sonora, IV. 78-80. 
standing the excellent service of José M. Carrasco, Inspector of the Military Colonies of the West, and Commander of the frontier forces, there were one hundred and sixty-seven killed, fortyfour wounded, and a number taken prisoner.

In 1852 the pages of the Sonoran paper were largely taken up with the filibustering schemes of Raousset-Boulbon. There was specifically reported this year, however, one hundred and nineteen deaths and one hundred and one prisoners, and the following year reached the climax for the period with a total of two hundred and sixteen deaths and thirteen captives reported. ${ }^{91}$

Statistics as to the number of deaths, captives and wounded-and there were a large number of the latter-serve to convey only a partial idea of the losses of the frontier states. There must be taken into consideration also the interruption of communications, the paralyzation of industry, the destruction of ranches and hacienclas, the theft of provisions, stock, and everything transportable, and the constant peril under which the inhabitants lived. A few instances will serve to convey an impression of these evils.

An incomplete report of May, 1848, stated that the Apaches had depopulated or obstructed twenty-six minerales, thirty haciendas and ninety ranchos in Sonora. ${ }^{92}$ In January of the following year the acting prefect of the district of Ures, in a letter addressed to the Governor, urged him to represent to the National Government in strong terms the plight of the fifty-one towns under his charge. Fronteras, Cocóspera, Tubac, and three other towns had been completely abandoned. ${ }^{93}$ Speaking especially of the Rio Grande frontier, the Border Commission sent out by Mexico in 1873 declared that one of the greatest damages resulting from these raids "had been the suspension of every kind of industry and the lack of confidence in beginning afresh arising from the insecurity of the fruit of their [the citizens'] labors". ${ }^{94}$ The permanent deputation of Chihuahua in a report made in

\footnotetext{
${ }^{91}$ For the Indian raids on Sonora, 1851-1853, see Pinart Transcripts, Sonora, IV. and V.

22 Pinart Transcripts, Sonora, IV. 69-70.

${ }^{3}$ Ibid., IV. 107.

24 Mexican Border Commission of 1873, Report, p. 257.
} 
the latter part of 1852 declared that the herds of that state had already been destroyed and the fields had long since been deserted. It then gave a vivid picture of the Apaches who from their hiding places constantly sought an opportunity to "pounce upon the yokes of oxen which graze without the necessary guard, the mule drove which leaves the corral to go to water, . . . the wood-cutter who . . . goes, with two or three asses which are to carry his kindling, to seek his sustenance in the mountains, the luckless drivers of the carts coveted by the savages for the oxen which draw them". ${ }^{95}$ Finally, one of the papers of Nuevo León declared: "The first thing that meets our eyes is always something about savage Indians. Agriculture, industry, and commerce relapse into insignificance, the revenues cease, tranquillity is lost by constant fear of the peril which threatens life, honor, and family interests; all in short presents the most doleful picture of misfortune and desolation". ${ }^{96}$

Reliability of the Reports.-These accounts are not given as absolutely reliable. The, newspapers consulted are no more worthy of credence than the average newspapers of any frontier section clamoring for aid from the central government. Moreover, the polemic nature of the report of the Mexican Commission makes one a little skeptical in regard to its trustworthiness. Three hundred and sixty-six claims, amounting to $\$ 31,000,000$ and arising from the depredations of this period, were presented to the Commission created in 1868 , but they were never considered upon their merits. ${ }^{97}$ Nevertheless, the array of statistics presented will serve to give the impression that the border states were in a lamentable condition, a fact which is not denied by United States officials who served on the southwestern border during the time. ${ }^{98}$

${ }^{95}$ El Universal, November 27, 1852.

${ }^{96}$ Quoted in Mexican Border Commission of 1873, Report, p. 289.

${ }^{97}$ Moore, History and Digest of International Arbitrations, in House Misc. Doc. 212, 53d cong., 2d sess., pp. 1305-1308.

${ }_{98}$ See especially Report of Secretary of War, in House Ex. Doc. 2, 32d cong., 1st sess. p. 105 et seq.; Brooke to Scott, May 28, 1850, Senate Ex. Doc. 1, part II., 31st cong., 2d sess., p. 35; Abel, Official Correspondence of James S. Calhoun, pp. 54-55, 160-162, 270, 394; Report of Secretary of Interior, in House Ex. Doc. 2, 32d cong., 1st sess., p. 502 . 
Mexican Complaints.-Complaints against the United States for failure to comply with treaty obligations were numerous and widespread. The Junta of Congress formed in 1849 for the supervision of matters pertaining to the defense of the northern frontier, declared in the preamble to its plan that since the fulfillment of Article XI. by the United States would furnish the means of radically terminating the Indian War, the Junta ought never to lose sight of that article. It recommended, therefore, that the general government furnish a report "upon this important point, as a basis upon which to predicate the action most expedient for the welfare of the states in question". ${ }^{99}$ Inspector Jauregui in his report to the Junta, dated July 8, 1849, declared that no effective defense of the frontier could be had until the United States lived up to its obligation. In 1851, the sub-Inspector of the Chihuahuan colonies declared that Mexico might as well cease to expect the United States to restrain the Indians and take matters into its own hands; the sub-Inspector of the East asked permission to cross the Rio Grande in pursuit of the Indians; and complaint after complaint was raised in Sonora. ${ }^{100}$ Finally, the plan of defense formed by the frontier states and published in February, 1852, contained the following article:

"The governments of the coalition will earnestly urge the supreme national authorities to obtain from the government at Washington permission for the Mexican forces to cross the Rio Grande, and attack the nomadic tribes which reside in that territory; without omitting to demand constantly and vigorously the fulfillment of Article XI. of the treaty of Guadalupe, and an indemnification for the losses which the frontier has heretofore suffered from the non-fulfillment of that article". ${ }^{101}$

On March 20, 1850, La Rosa, the Mexican minister at Washington, acknowledged orders of the United States War Department which Clayton had enclosed in confidential notes directed to him during the same month. La Rosa said that he had communicated them to his government, and that due credit would be

\footnotetext{
${ }^{99}$ Mexican Border Commission of 1873, Report, p. 298.

${ }^{100}$ See especially Pinart Transcripts, Sonora, IV. 113, 244-245.

101 Mexican Border Commission of 1873, Report, p. 340.
} 
given to the attempts to fulfill Article XI. but he declared that previous efforts of the United States to that effect had been unsuccessful from "the want of military force sufficient to restrain and repress the Indians, and from the want, moreover, of funds to cover the great expenses rendered necessary" by the article. $\mathrm{He}$ was persuaded that the only advantage. which could accrue to Mexico from the late treaty, the only advantage which could "compensate her for the many sacrifices" which that agreement "rendered necessary" was the exact fulfillment of the stipulation in regard to the Indians. To obtain this the Minister considered his chief duty. In conclusion he declared that Mexico would "continue . . . to use all its efforts for the repression of the tribes on those frontiers". ${ }^{102}$

In December of the same year, La Rosa again called attention to the Indian incursions. He reminded Webster, now Secretary of State, that it was "daily becoming more and more indispensable that the government of the United States should adopt the promptest and most active measures in order to prevent the incursions of the Indian savages of the United States upon the population of the Mexican frontier". He expressed the confident hope that Congress in accordance with the President's recommendation, would give the matter "all the attention which its importance" required. He was especially anxious in regard to the matter in view of the season of the year and the weakened condition of the frontier population resulting from the failure of their crops. ${ }^{103}$

The Abrogation of Article XI.-The first intimation that the United States was contemplating means of obtaining a release from the obligations of the article is found in a letter addressed by Letcher to Webster under the date of December 14, 1851. In this communication the American Chargé complained that certain benevolently disposed gentlemen of New York and Washington City had "warned her [Mexico] in the most solemn manner against making any agreement to change the eleventh article of the treaty of Guadalupe Hidalgo". Six days ago he declared

102 Senate Ex. Doc. 44, 31st cong., 1st sess.

${ }^{103}$ House Ex. Doc. 4, 31st cong., 2d sess. 
that he had had the "fairest prospect imaginable" to procure a change "altogether satisfactory" to his government. The advances of these gentlemen had broken into his plans, but fortunately he had never committed himself upon "this subject, in any manner whatever". He still believed he should be able to obtain the desired change. ${ }^{104}$

Early in January, 1852, the new Minister of Relations, José F. Ramírez, declared that from the first moment he had put himself in relations with Letcher (September or October, 1851), this functionary had indicated his willingness to settle all the difficulties between the two countries. "After repeated and lengthy conferences", Letcher had agreed that the points to receive early discussion should be: "1st. A modification of the treaty of Tehuantepec. 2d. The same in regard to the eleventh article of the treaty of Guadalupe. 3d. and 4th. A settlement of mutual claims between Mexico and the United States." Ramírez complained because the United States Chargé had as yet failed to take up the matter, and went on to declare that in laying down the bases upon which negotiations were to proceed, he had maintained that the modification of Article XI. should be "upon the ground of facilitating the fulfillment of its conditions, and of rendering its purpose effective", since the United States alleged that it was "impossible to accomplish this" as the treaty then stood. Moreover, he took a step in advance of La Rosa by demanding that, "in virtue of this obligation-contracted and not fullfilled -means should be devised to indemnify Mexico for the fatal consequences" which had resulted. ${ }^{105}$

During the remainder of the year negotiations regarding the Isthmus of Tehuantepec took precedence over all other questions, so that the subject of Indian depredations seems in a measure to have been passed over. ${ }^{106}$ But Mexico had not forgotten the matter. Under date of August 12, 1852, the Minister of Relations requested that the Governor of Sonora have prepared a detailed statement of Indian raids perpetrated upon his

${ }^{104}$ Senate Ex. Doc. 97, 32d cong., 1st sess. p. 105.

${ }^{105}$ Ramírez to Letcher, June 3, 1852, ibid., pp. 124-125.

106 Ibid., pp. 125-163; Senate Rep. 355, 32d cong., 1st sess. 
state with a view of obtaining damages. ${ }^{107}$ Harper's Magazine reported that the Constitucional, the official organ of Mexico City, contained the announcement that negotiations had been entered upon, the object of which was the release of the United. States from Article XI. for the sum of $\$ 6,000,000.108$ In November of the next year, James Gadsden communicated to Mexico his objection to the article. ${ }^{109}$ The matter was finally settled by the Gadsden Treaty which freed the United States from the obligations entailed by Article XI. of the former treaty.

Article III. of this treaty provided that Mexico should be paid $\$ 10,000,000$ for the new boundary designated in Article I. and for relieving the United States from responsibility for the Indians. ${ }^{110}$ How much was to be paid for each of these considerations, or the amount of indemnity asked by Mexico, is not known. The correspondence concerning the negotiations has never been published. While the House was considering the appropriation to carry the treaty into effect, Jones of Pennsylvania declared that it was a wellknown fact that Mexico had presented with vouchers claims amounting to $\$ 16,000,000$, while reports were circulated to the effect that $\$ 40,000,000$ had been demanded. Other members believed that they had been credibly informed that Fillmore had offered first $\$ 5,000,000$ and then $\$ 7,000,000$ for freedom from the obligation. At any rate, the debates show considerable anxiety to be rid of a responsibility which might cause no little trouble in the future. ${ }^{111}$

\section{CONCLUSION}

The United States assumed responsibility by the treaty of Guadalupe Hidalgo for the conduct of the Indians on the borders of Mexico because that country would not otherwise consent to

107 Pinart Transcripts, Sonora, V. 128.

${ }^{108}$ November, 1852 , p. 836.

${ }^{109}$ Herbert E. Bolton, Guide to materials for United States History in the Archives of Mexico (Washington, 1913). Bolton gives the year 1852, but this is perhaps a misprint as Gadsden did not present his credentials to the Mexican government until August 18, 1853. Harper's Monthly, December, 1853, p. 835.

${ }^{110}$ Malloy, Treaties, I. 1122-1123.

${ }^{111}$ Globe, 33d cong., 1st sess., pp. 1520-1542. 
part with the territory desired. Had the difficulties of the obligation been fully realized, perhaps the agreement to restrain the veritable multitude of Indians residing in the new domain and upon the borders of Texas would have been entered upon with no little hesitancy. As a matter of fact, the official of the United States knew neither the number nor the nature of these tribes, nor could they have had any definite conception of the cost of subduing them. Moreover, this enormous problem thrust itself upon the government at a time when the slavery issue made impossible rapid and unbiased action in regard to the Southwest. Consequently, six years passed before a well-defined policy regarding the Indians in question was adopted.

From this distance it would seem that the only adequate way of dealing with the problem would have been to place the tribes, by means of sheer force, upon reservations remote from the boundary line where they could have been held in surveillance by the combined efforts of an efficient corps of agents and a strong military force consisting mainly of cavalry. If Congress, bent upon economy and retrenchment, failed to provide for this, at least that body might have been expected to extend the laws regulating trade and intercourse with the Indians over the natives of the Southwest. Even this measure, however, was neglected entirely with regard to Texas, and for almost three years in the case of New Mexico.

Therefore, a small number of Indian agents who were handicapped by insufficient means and lack of legal aid, along with a military force inadequate both in kind and in number, were left to deal with the situation as best they could. They were instructed to keep the treaty obligations to Mexico in mind; and the delivery of Mexican captives, as well as the provisions of the various Indian treaties made, evidenced the fact that their instructions were not forgotten. Yet these forces were by no means able to handle the situation.

It may be said to the credit of the central government of Mexico, and of the Mexican frontier states, that they made no inconsiderable effort to defend themselves: The former endeavored to organize the militia and to plant military colonies 
along the northern frontier, while the latter offered scalp and prisoner bounties, and formed a coalition for defence from the common peril. If these plans proved ineffective, it was due not so much to lethargy and indifference, as to sparseness of frontier population, an empty treasury, and political convulsions which rendered a consecutive policy out of the question.

There is ample evidence that the population of the North Mexican States suffered grievously from Indian depredations during the period under consideration. These unfortunate people complained both of inadequate assistance from their home government and of lack of good faith on the part of the United States. Their complaints were communicated to Washington with the request that more efficient measures be taken to restrain the Indians. At first, little or nothing was said concerning indemnity, but gradually this became an important factor, so that the United States grew more and more anxious to free itself from a responsibility which, under the circumstances, could be fulfilled only with great difficulty. Negotiations to this effect were begun as early as December, 1851, but other matters deemed of greater importance interfered until two years later when the desired release was obtained by furnishing a bankrupt government means which contributed to the maintenance of its solvency. How much of the $\$ 10,000,000$ paid Mexico by the third article of the treaty of 1853 was considered as indemnity and how much was allowed for what has become known as the Gadsden Purchase, is, in the absence of documentary evidence, impossible to ascertain. From the speeches made in the House while the appropriation of the necessary sum was under discussion it seems evident not only that the members of that body considered a large portion of the amount as damage money, but that release from the obligations of Article XI. had no little weight in determining the vote upon the measure. Indeed, it may have been a more influential factor than the route for a Pacific railway which the change of boundary was designed to acquire.

University of California

J. Fred Rippy.

October 22, 1918. 


Lithomount

Pamphlet

Binder

Gaylord Bros.

Makers Calif Stockton, 1988
PAT. JAN 21,

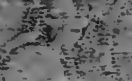

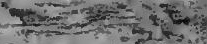

vis

-2:

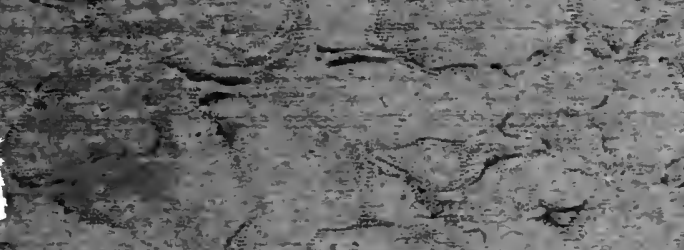

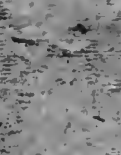

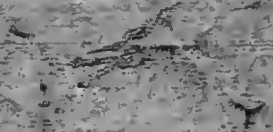

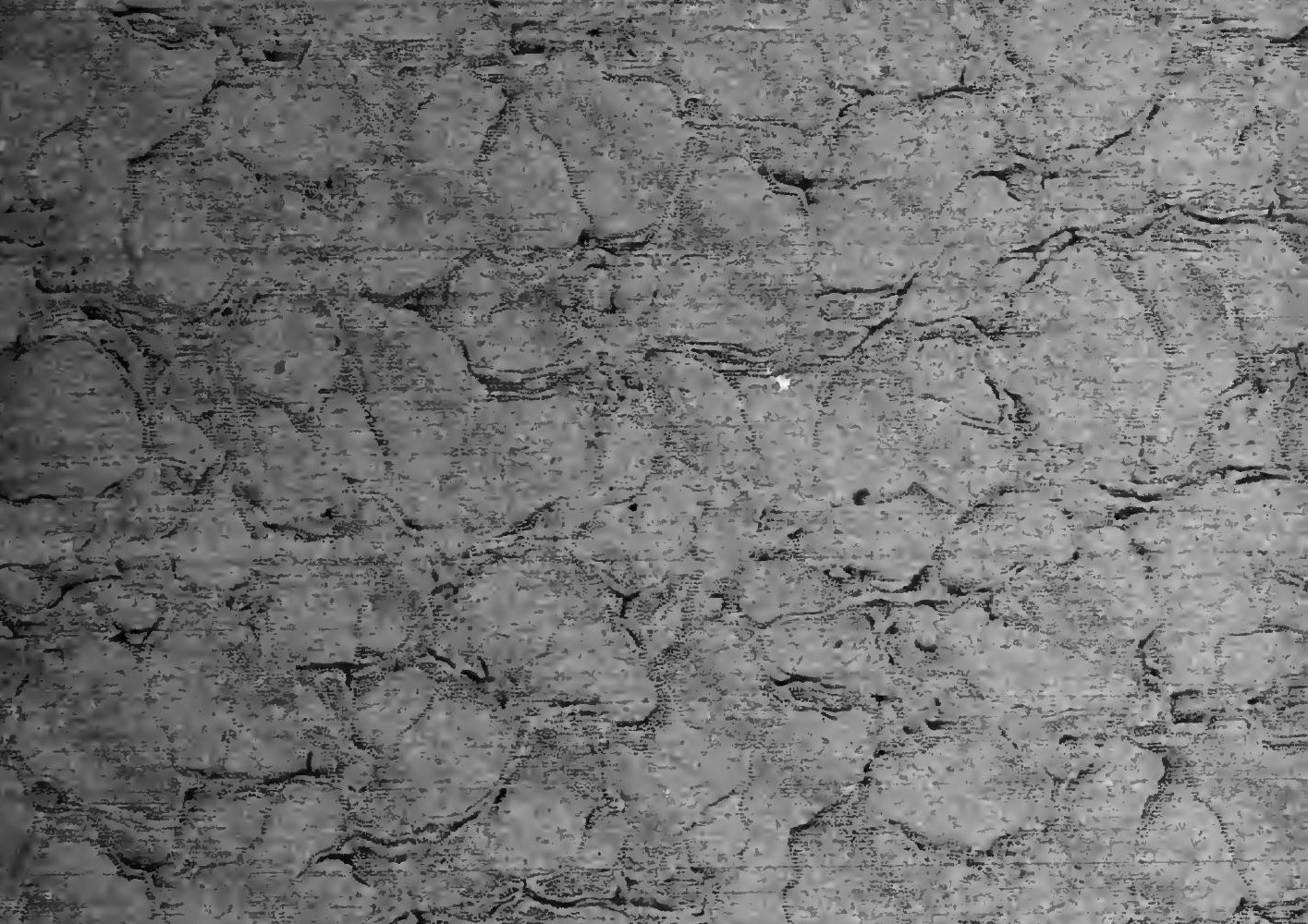

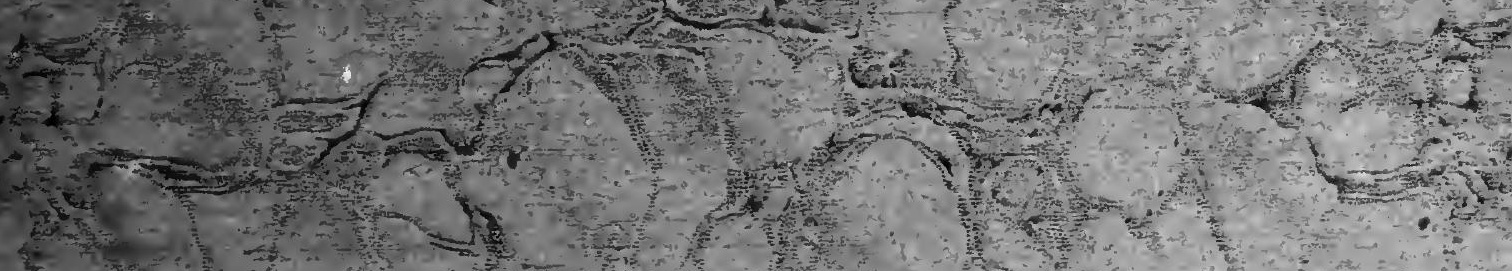

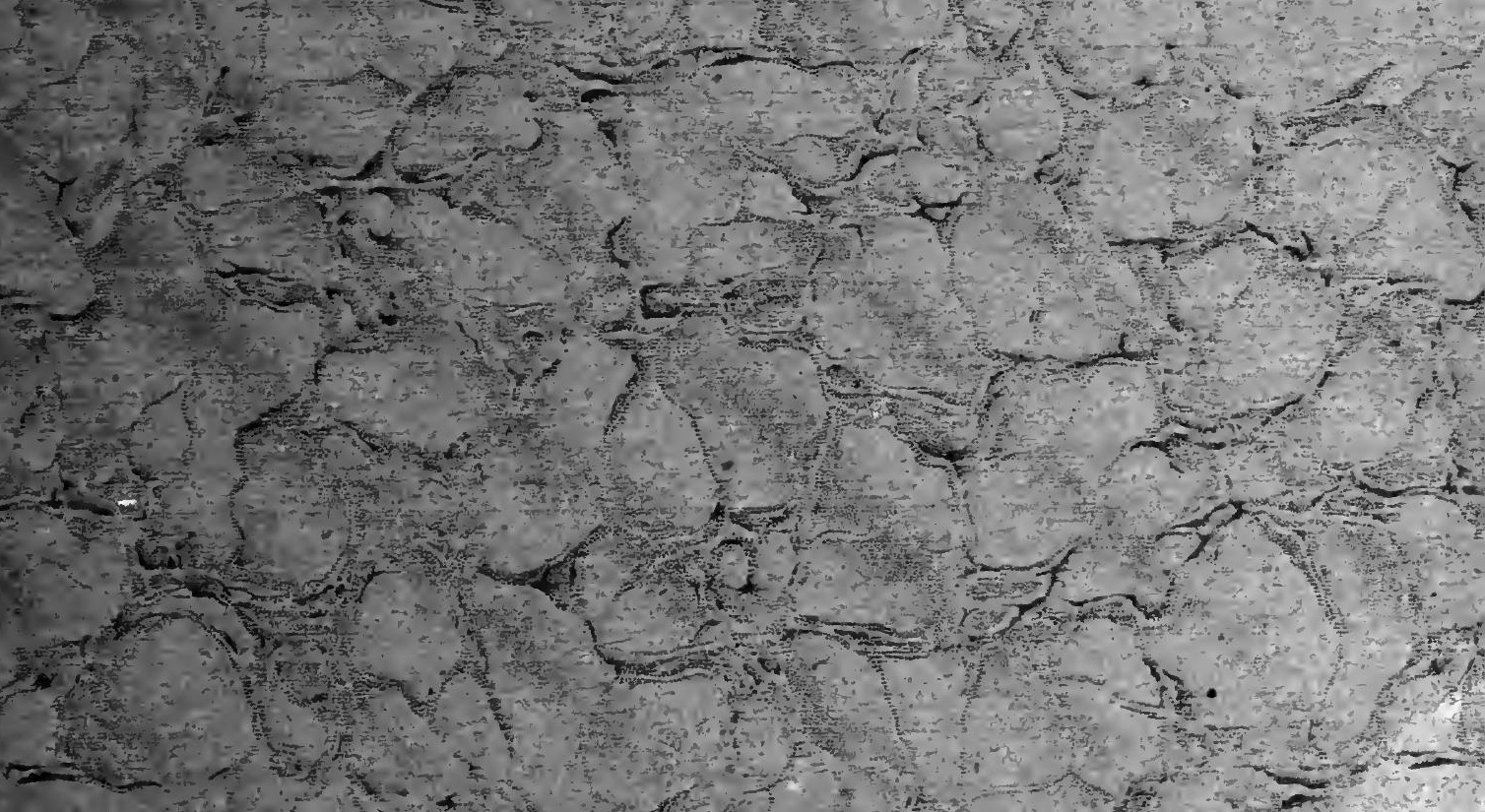


